\title{
Desa Adat Dalam Pengelolaan Tanah Adat Bali \\ Berbasis Kebijakan Daerah
}

\section{Dewa Gede Agung Satria Yoga Purnama1, Anak Agung Istri Ari Atu Dewi²}

1Fakultas Hukum Universitas Udayana, E-mail: satriapurnama95@gmail.com ${ }^{2}$ Fakultas Hukum Universitas Udayana, E-mail: ari_atudewi@unud.ac.id

\begin{tabular}{l}
\hline Info Artikel \\
\hline Masuk: \\
Diterima : \\
Terbit: \\
Keywords : \\
Desa adat; \\
Manage custumary lands; \\
regional policy \\
\\
\\
\\
\\
Cori_atudewi@unud.ac.i \\
Dorresponding Author: \\
Dewi, E-mail: \\
Kata kunci: \\
Pesa adat; \\
Kebiajakan Daerah \\
\end{tabular}

\begin{abstract}
Desa adat as customary law communities have autonomy based on constitutional rights. However, in the legislaton does not regulate the status of desa adat as a legal subjects. Unclear about the status of desa adat including custumary land management. In disccusing issues of the unclear of the status desa adat to use normatif methode. The porpuse of this research is to exemine the clarity of the status of desa adat as a legal subject to manage the custumary land in Bali. The results of this study is a desa adat can be come legal subject which is indicated by the arrangement in Decree of the Minister of Agrarian and Spatial Planning / Head of the National Land Agency of the Republic of Indonesia Number 276 / KEP-19.2 / X / 2017 concerning Appointment of Pakraman Village in Bali Province as the Subject of Communal Ownership Rights and the authority of desa adat in the management of customary lands is regulated in Perda 4 of 2019 concerning Desa adat in Bali
\end{abstract}

\footnotetext{
Abstrak

Desa adat sebagai kesatuan masyarakat hukum adat yang memiliki otonomi berdasarkan hak konstitusionalnya. Namun penjabaran dalam Peraturan perundang-undangan tidak ada mengatur mengenai status desa adat sebagai subyek hukum. Ketidakjelasan status desa adat menyebabkan desa adat kurang berani melakukan tindakan terhadap tanah adat termasuk pengelolaan tanah adat. Dalam membahas persoalan ini metode penelitian normatif tepat digunakan untuk menjawab isu ketidakjelasan status desa adat. Tujuan penelitian ini untuk mengungkap kejelasan status desa adat sebagai subjek hak kepemilikan atas tanah yang berimplikasi pada
} 


\section{$X x x x x \times x$}

\section{Pendahuluan}

Desa adat sebagai Kesatuan Masyarakat Hukum Adat yang diatur dalam Pasal 18 B ayat (2) UUD NRI Tahun 1945 yang menentukan bahwa Kesatuan Masayarakat Hukum Adat yang selanjutnya disebut KMHA dilindungi dan diakui oleh negara dengan hak tradisionalnya sepanjang masih hidup dan sesuai dengan perkembangan serta tidak bertentangan dengan NKRI. Dalam hal ini Desa adat mempunyai otonomi dalam mengatur desa adatnya.

Konsep otonomi secara umum dapat diartikan sebagai kewenangan dan kewajiban untuk mengatur dan mengurus urusan rumah tangganya sendiri. ${ }^{1}$ Apabila meminjam Tujuan otonomi dalam konteks pemerintahan Daerah, bahwa tujuan otonomi daerah adalah mempercepat kesejahteraan masyarakat melalui peningkatan pelayanan, pemberdayaan dan peran serta masyarakat. ${ }^{2}$ Tampaknya dalam pemahaman otonomi dalam pemerintahan daerah juga dapat dipahamahi dalam konteks pemerintahan desa adat.

Desa adat yang merupakan salah satu KMHA yang berkedudukan di Bali mempunyai otonomi yaitu hak dan kewajiban dalam mengatur dan menyelenggarakan pemerintahan desa adatnya. Otonomi desa adat dapat dibagi menjadi 3 (tiga) lingkup yaitu pertama, lingkup kewenangan desa adat

\footnotetext{
1 Dewi, A. A. I. A. A. (2019). Penyusunan Perda Yang Partisipatif: Peran Desa Pakraman Dalam Pembentukan Peraturan Daerah. Zifatama Jawara, hal. 126.

2 Simanjuntak, B. A. (2018). Strategi dan Problem Sosial Politik Pemerintahan Otonomi Daerah Indonesia: Konsep Mensukseskan Otonomi Daerah. Yayasan Pustaka Obor Indonesia. Hal 156.
} 
membentuk aturan hukum adatnya sendiri; kedua, kewenangan desa adat dalam menerapkan dan menyelenggarakan hukum adatnya sendiri; ketiga, kewenangan desa adat dalam menjatuhkan hukumnya sendiri. Dalam hal ini otonomi desa adat adalah penuh yang berlaku di wilayah dan diterapkan pada masyarakatnya sendiri. Dalam hal penyelesaian kasus adat atau pelanggaran adat, desa adat dalam menyelesaiakan berdasarkan awig-awig dan dilakukan oleh prajuru adat. ${ }^{3}$

Sebagaimana tujuan dari otonomi untuk menunjang otonomi desa adat dalam mewujudkan kesejahteraan masyarakat desa adatnya, maka desa adat harus mampu mengelola potensi dan harta kekayaan desa adat. Harta kekayaan desa adat dapat berupa harta kekayaan materiil (berwujud) dan in materiil (tidak berwujud). Harta kekayaan desa adat yang berwujud dapat berupa tanah adat. Keberadaan tanah adat dengan masyarakat adat di wilayah desa adat mempunyai hubungan sosial relegius. Dalam arti bahwa tanah adat mempunyai fungsi sosial dan relegius bagi mayarakat desa adat.

Berkaitan dengan pengelolaan harta kekayaan desa adat yang berupa tanah adat, desa adat masih kebingungan dalam mengelola tanah adatnya. Hal ini disebabkan dalam pengelolaan tanah adat oleh desa adat terdapat dua (2) pemahaman yang berbeda yaitu bahwa dalam mengelola tanah adat harus berdasarkan ketentuan peraturan perundangan-undangan dan di sisi lain pengelolaan tanah adatcukup hanya berdasarkan aturan hukum adat (awigawig). Adanya dua (2) pemahaman yang berbeda ini menyebabkan tidak ada keleluasaan atau ketakutan desa adat dalam mengelola tanah desa adat. Seperti kasus pengelolaan objek wisata tirta empul tampak siring dan pengelolaan wilayah pantai sanur yang pernah menjadi persoalan hukum yang harus diselesaikan berdasarkan hukum yang berlaku. Situasi seperti ini membuat desa adat kurang berani dan ketakutan dalam mengelola tanah adat yang dimiliki oleh desa adat. Penelitian ini menjadi penting, karena ingin mengungkap dan

\footnotetext{
3 Dewi, A. A. I. A. A. (2014). Eksistensi Otonomi Desa Pakraman dalam Perspektif Pluralisme Hukum. Jurnal Magister Hukum Udayana (Udayana Master Law Journal), 3(3), hal. 521.
} 
menjelaskan sejauh mana kewenangan desa adat dalam mengelola tanah adat untuk tujuan kesejahteraan masyarakat desa adatnya. Penelitian terdahulu belum ada yang mengangkat sebagaiamana topik dalam penelitian ini. I ketut Sudantra meneliti tentang kedudukan tanah milik desa pakraman berdasarkan Keputusan Menteri Agrarian dan Tata Ruang. Dalam penelitianya di temukan bahwa implikasi Keputusan Meteri agraria dan Tata Ruang dapat bersifat positif yaitu bahwa adanya kepastian hukum terhadap keberadaan tanah adat dan dapat bersifat negatif yaitu bahwa tanah adat telah diserahkan pengelolaannya pada perseorangan (krama desa adat) dengan didaftarkannya atas nama perseorangan. ${ }^{4}$ Dalam konteks seperti ini perlu dilakukan kajian yang lebih mendalam terkait dengan apakah boleh desa adat mengelola tanah adat untuk meningkatkam pendapatan desa adat untuk tujuan kesejahteraan masyarakat desa adatnya dan apa dasar kewenangan desa adat dalam mengelolaan tanah adatnya.

Berdasarksan isu yang diangkat, maka tujuan penelitian ini untuk mengungkap dan menjelaskan dasar kewenangan desa adat dalam mengelola tanah adat sehingga mendapat kejelasan dan kepastian bagi desa adat dalam bertindak terutama dalam mengelola tanah-tanah adat.

\section{Metode Penelitian}

Di dalam membedah isu hukum dalam penelitian ini maka metode penelitian yang digunakan adalah metode peneliian normatif yang mengungkap dasar kewenangan desa adat dalam pengelolaan tanah-tanah adanya. Berangkat dari adanya dua (2) pemahaman yang berbeda yang berjung pada ketakutan dan ketidakleluasaan desa adat dalam bertindak yaitu pengeloaan tanah adatnya. Bahan hukum yang dugunakan adalah bahan hukum primer yaitu peraturan perundang-undangan dan awig awig desa adat, sedangkan bahan hukum sekunder, buku dan bahan bahan yang berkaitan dengan topik yang disajikan.

\footnotetext{
4 Sudantra, I. K. (2018). Implikasi Keputusan Menteri ATR/Kepala BPN Nomor 276/KEP19.2/X/2017 Terhadap Kedudukan Tanah Milik Desa Pakraman. Jurnal Magister Hukum Udayana (Udayana Master Law Journal), 7(4), 546-564.
} 
Selanjutnya teknik penelususran bahan hukum adalah studi dokumen serta menganalisisnya secara deskripsi kualitatif

\section{Hasil Dan Pembahasan}

\subsection{Tanah adat dan dasar kepemilikan desa adat}

Perspektif sejarah menentukan bahwa munculnya istilah tanah adat tidak terlepas dari adanya sistem hukum yang pernah berlaku di Indonesia. Berlakunya sistem hukum di Indonesia tersebut menjadi dasar berlakunya hukum pertanahan di Indonesia sebelum berlakunya UUPA. Sistem yang berlaku pada waktu itu adalah hukum adat dan hukum barat, sehingga ada dua macam bentuk tanah pada waktu itu yaitu Tanah Indonesia dan Tanah Barat yang disebut tanah Eropa. ${ }^{5}$

Sejak tahun 1960, hukum pertanahan diatur dengan UU 5 tahun 1960 tentang UUPA, dalam Pasal 5 UUPA yang menegaskan bahwa hukum agraria yang berlaku... aialah hukum adat sepanjang tidak bertentangan dengan kepentingan nasional, negara. Dalam konteks ini dapat dipahami bahwa keberlakuan huum pertanahan di Indonesia berdasarkan pada hukum adat., sehingga keberlakuan hukum adat termasuk tanah adat mendapatkan dasar hukum yang pasti.

Berkaitan dengan keberadaan tanah adat di Bali, Windia dan Sudantra menegaskan bahwa tanah milik desa adat berupa 1) tanah desa yang dalam arti sempit disebut dengan tanah druwe desa yaitu tanah-tanah yang dimiliki langsung oleh desa adat baik berupa tanah setra, pasar, lapangan, tanah bukti, baai banjar dan lain sebagainya. 2) Tanah Pekaranggan Desa (PKD) yaitu tanah desa yang dimiliki oleh desa adat namun diberikan penguasaannya pada krama desa adat sebagai tempat tinggal dengan ukuran luasnya ditentukan oleh desa adat seperti sikut satak, sikut samas dan lains ebagainya. 3) Tanah Ayahan desa (AYDS) dipahami

5 Soerojo Wignjodipuro, 1979, Pengantar dan Asas-Asas Hukum Adat, Edisi ke tiga, Alumni Bandung, hal 248. 
bahwa tanah tanah yang dimiliki oleh desa adat yang diberikan dan diserahkan kepada krama desa adat dengan menikmati hasil serta melekat juga dengan kewajiban (ayahan ) ke desa adat. ${ }^{6}$

Selain 3 (tiga ) jenis tanah adat, ada juga yang disebut dengan tanah pura. Tanah puradipahami sebagai tanah yang diperuntukan untuk bangunan pura (tegak pura) ataupun tanah tanah yang diperuntukan bagi keperluan pura. $^{7}$ Dalam konteks ini tanah pura dan tanah adat dapat dikatagorikan milik desa adat dan harus dikelola oleh desa adat untuk kesejahteraan krama desa adat.

Berkaitan dengan dasar kepemilikian tanah adat oleh desa adat, maka terlebih dahulu perlu dipahami Pasal 18 B ayat (2) UUD NRI Tahun 1945. Pamahaman terhadap Pasal 18 B ayat (2) UUD NRI Tahun 1945 menyatakan bahwa Kesatuan Masyarakat Hukum Adat (desa adat) mempunyai hak tradisional termasuk hak-hak atas tanah yang telah ada semenjak adanya desa adat. Keberadaan hak atas tanah adat tersebut dilindungi dan diakui oleh Negara. Demikian juga dalam Pasal 2 ayat (4) dan Pasal 3 UUPA jelas disebutkan bahwa diakuinya hak ulayat atau hak desa adat terhadap tanah adat.

Pemahaman Pasal 18 B ayat (2) dan Pasal 2 dan Pasal 3 UUPA jelas menegaskan bahwa hak atas tanah adat oleh desa adat diakui dan dilindunggi oleh negara. Desa adat dalam konteks pengelolaan tanah adat mempunyai hak tradisional dalam arti desa adat dapat melakukan tindakan dan perbuatan pada tanah adatnya masing masing berdasarkan hukum adatnya (awig-awig). Menarik mencermati Pasal II ketentuan-ketentuan konversi UUPA yang menentukan bahwa "tanah... hak atas druwe desa, hak atas druwe desa sejak berlakunya UUPA menjadi hak milik kecuali jika yang mempunyai tidak memenuhi syarat...". Ketentuan ini dimaknai

\footnotetext{
6 Wayan P windia dan Ketut Sudantra, 2016, Pengantar Hukum Adat Bali, Swasta Nulus bekerjasama dengan Bali Shanti, Pusat Pelayanan Konsultasi Adat dan Budaya Bali LPPM Unud dan Puslit Hukum Adat LPPM Unud, hal.164.

7 Ibid.
} 
bahwa pembentuk UUPA mengisyaratkan bahwa tanah druwe desa merupakan hak milik sebagai hak yang turun temurun. Dalam hal ini dipahami juga bahwa desa adat baru dapat diakui sebagai subjek hak milik apabila memenuhi syarat yang telah ditetapkan oleh pemerintah, diantaranya: sebagai warga negara dan badan hukum yang ditetapkan oleh Pemerintah. Respon terhadap penunjukan sebagai subjek hak milik atas tanah ditunjukan dengan dikeluarkannya PP 38 Tahun 1963 yang menunjuk badan hukum yang dapat mempunyai hak milik atas tanah yaitu 1) bank negara, 2)perkumpulan-perkumpulan koperasi pertanian, 3) badanbadan keagamaan. Namun yang menjadi persoalan dasar kepemilikan desa adat terhadap tanah adat belum ada kepastian hukum. Oleh karena itu dasar kepemilikan desa adat terhadap tanah adat menjadi tidak jelas, sehingga desa adat belum berani atau ragu ragu dalam melakukan pengelolaan terhadap tanah adatnya.

Pada tahun 2017 mulai ada titik terang terhadap kejelasan Desa adat sebagai subjek hak kepemilikan atas tanah dengan dikeluarkannya Keputusan Menteri Agraria dan Tata Ruang/ Kepala Badan Pertanahan Nasional Republik Indonesia Nomor 276/KEP-19.2/X/2017 tentang Penunjukan Desa Pakraman di Provinsi Bali sebagai Subjek Hak Kepemilikan Bersama (Komunal) Atas Tanah. Penunjukan Desa adat sebagai subjek hak kepemilikan atas tanah ini menjadi kejelasan bagi status desa adat sebagai subjek hukum termasuk dalam kepemilikan tanah adat. Dengan demikian kejelasan status desa adat sebagai subjek hak milik atas tanah memberi kejelasan juga bahwa desa adat dapat melakukan pengelolaan terhadap tanah adat untuk tujuan kesejahteraan masyarakat adat dan keberlanjutan desa adat.

\subsection{Kewenangan Desa adat dalam Pengelolaan Tanah Adat berdasarkan Kebiajakan Daerah}

Berdasarkan pemahaman sebelumnya bahwa desa adat dan tanah adat mempnyai hubungan yang erat. Fungsi tanah adat sebagai sosial 
relegius memberikan manfaat bagi krama desa adat baik secara kelompok maupun individu. Krama desa adat yang yang menguasan tanah adat tidak boleh sampai merugikan desa adat karena dengan menguasai tanah adat krama desa adat terikat dengan ayah-ayahan desa. Selain itu fungsi tanah adat adalah sebagai fugsi ekonomi yaitu bahwa tanah-tanah adat dapat dikelola oleh desa adat untuk kesejahteraan desa adat.

Perlu juga diketahui bahwa karakter dari tanah adat adalah 1) bahwa krama desa adat dapat mengunakan tanah sebagai dasar untuk kehidupannya, 2) orang yang bukan krama desa adat tidak dapat menggunakan hak kecuali ada ijin dari desa adat, 3) orang lain yang bukan krama desa adat, apabila ingin menggunakan hak itu harus membayar kepada desa adat, 4) desa adat harus bertanggungjawab terhadap segala peruatan hukum yang terjadi di atas tanah adat tersebut, 5) desa adat tidak boleh memindahtangankan tanah adat kepada siapa saja, 6) desa adat dapat mencampuri penggunaan tanah-tanah adat yang telah digarap oleh krama desa adat agar dimanfaatkan secara wajar. ${ }^{8}$ Berdasarkan karakteristik tanah adat dari Sirtha jelas bahwa desa adat dengan kewenangannya dapat mengelola tanah desa adat.

Memahami kewenangan desa adat, perlu dipadankan dengan kewenangan dalam hukum negara. Bahwa kewenangan mempunyai peranan penting dalam penyelenggaraan suatu pemerintahan termasuk pemerintahan desa adat. Dalam hukum negara ,Prajudi menjelaskan kewenangan merupakan kekuasaan formal yang berasal dari kekuasaan yang berasal dari legislative dan kekuasaan administratif. ${ }^{9}$ Dalam konteks ini lebih jelas dipahami bahwa kewenangan dipahami kemampuan untuk

\footnotetext{
8 I Nyoman Sirtha, 2001, Pengkajian Hukum Adat Bali: Inventarisasi dan Identifikasi Karakteristik Hukum Tanah Adat Bali d I Kabupaten Gianyar, Laporan Penelitian, Kerjasama Pemerintah Daerah Provinsi Bali denggan Fakultas Hukum Universitas Udayana.

9 Dewi, A. A. I. A. A. (2015). Dasar Kewenangan Pemerintah Daerah Kabupaten Badung dalam Memberikan Standar Pelayanan Bagi Perempuan dan Anak Korban Kekerasan. Jurnal Magister Hukum Udayana (Udayana Master Law Journal), 4(3), hal 613.
} 
melakukan tindakan hukum tertentu yaitu tindakan yang menimbulkan akibat hukum dan menyangkup timbul atau lenyapnya akibat hukum).

Berdasarkan pemahaman kewenangan sebagaiman diuraikan sebelumnya tampaknya desa adat juga mempunyai kewenangan yang berdasarkan otomoni aslinya dan berdasarkan kebijakan daerah. Kewenangan berdasarkan kebijakan daerah dapat dipahami bahwa setiap tindakan hukum yang dilakukan harus berdasarkan kebijakan daerah.

Kebijakan daerah juga merupakan kebijakan publik yaitu suatu tindakan yang dilakukan berorientasi pada tujuan. Thomas $R$ Dye menegaskan kebijakan publik merupakan pelihan pemerintah untuk dilakukan atau tidak dilakukan. ${ }^{10}$ Dalam hal ini Kebijakan daerah yang dimaksud dalam penelitian ini adalah Peraturan Daerah. Konsep peraturan daerah merupaan peraturan yang ditetapkan oleh kepala daerah dengan persetjuan DPRD dan harus memeuhi syarat formil mempunyai kekuatan hukum dan mengikat untuk umum. ${ }^{11}$

Dalam kaitannya dengan Kebijakan daerah yang mengatur kewenangan desa adat dalam pengelolaan tanah adatnya diatur dengan Peraturan Daerah Provinsi Bali Nomor 4 Tahun 2019 tentang Desa adat (selanjutnya disebut dengan Perda Desa adat). Dalam Perda Desa adat ini memberi kewenangan dalam penyelenggraan desa adat berdasarkan otonomi aslinya dan berdasarkan nilai nilai luhur desa adat di Bali. Dala Pasal 1 angka 8 Perda Desa adat dijelaskan pengertian desa adat sebagai kesatuan masyarakat hukum di Bali yang memiliki wilayah, kedudukan, susunan asli, hak hak tradisional, harta kekeyaan, tradisi dan tata karam pergaulan hidup secara turun temurun dalam ikatan khayangan tiga serta

10 M Isrfan Islamy, 1997, Prinsip-Prinsip Perumusan Kebijaksanaan Negara, Jakarta, Bumi Aksara, hal.18. dapat juga dilihat dalam Dewi, A. A. I. A. A., \& Winarni, L. N. (2019). PENJABARAN PRINSIP DEMOKRASI DALAM PEMBENTUKAN KEBIJAKAN DAERAH. Supremasi Hukum: Jurnal Penelitian Hukum, 28(1), 83-107.

11 Saifullah, S., Ikbal, M., \& Thamrin, H. (2019). IMPLEMENTASI KEBIJAKAN PERATURAN DAERAH NOMOR 18 TAHUN 2016 TENTANG KAWASAN TANPA ROKOK DI RUMAH SAKIT ARIFIN NU'MANG KABUPATEN SIDENRENG RAPPANG. MODERAT: Jurnal Ilmiah Ilmu Pemerintahan, 5(1), hal. 48. 
berhak mengurus rumah tangganya sendiri. Memahami konsep desa adat ini jelas bahwa berdasarkan asas otonomi aslinya desa adat yang mempunyai tanah adat dapat mengelola tanah adatnya. Dalam arti tanah adat mempunyai fungsi sosial, relegius dan ekonomis. Dallam Pasal 3 huruf $b$ Perda Desa adat jelas menerangkan bahwamemberi kejelasan status dan kepastian hukum desa adat dalam sistem ketatanegaraan Republik Indonesia demi mewujudkan keadilan rakyat. Hal ini menunjukan bahwa desa adat jelas status hukumnya termasuk kejelasan status hukum dalam hak kepemilikan atas tanah adat. Lebih jelas lagi di atur dala Pasal 5 yang menentukan bahwa desa adat berstatus sebagai subyek hukum.

Dalam konteks pengelolaan tanah adat, yang menjadi dasar kewenangan desa adat diatur dalam Pasal 22 yang dengan tegas menegaskan bahwa desa adat bertugas mengembangkan perekonomian desa adat dan menjaga status hak atas tanah padruwen desa adat. Pasal 22 Perda Desa adat ini semakin mengukuhkan status desa adat dalam konteks pengelolaan tanah adat.

Hal ini menunjukan bahwa hukum negara mengakui dan melindungi kewenangan desa adat dalam hal pengelolaan tanah adat di wilayahnya. Desa adat dapat mengembangkan dan meningkatkan perekonomian desa adat melalui pengembangan dan pengelolaan tanah adat yang dimiliki oleh desa adat. Tampak ada harmonisasi anatara hukum adat dan hukum negara yang tertuang dalam Perda Desa adat.

\section{Kesimpulan}

Berdasarkan uraian di atas dapat dimpulkan bahwa setiap desa adat di Bali memiliki tanah adat yang berupa tanah druwen desa, tanah PKD, tanah AYDS dan tanah pura. Berkaitan dengan dasar kepemilikian tanah adat oleh desa adat telah diatur dalam Pasal 18 B ayat (2), UUPA dan Keputusan Menteri Agraria dan Tata Ruang/ Kepala Badan Pertanahan Nasional Republik Indonesia Nomor 276/KEP-19.2/X/2017 tentang Penunjukan Desa Pakraman di Provinsi Bali sebagai Subjek Hak Kepemilikan Bersama (Komunal) Atas Tanah. Kejelasan status Desa adat sebagai subjek hak 
kepemilikan atas tanah secara jelas juga diatur dalam Pasal 5 Perda Desa adat. Diakuinya dan jelasnya desa adat sebagai subjek hukum kepemilikan atas tanah menguatkan posisi desa adat dalam hal pengelolaan tanah adat di wilayah desa adat.

\section{DAFTAR PUSTAKA}

\section{Buku}

Dewi, A. A. I. A. A. (2019). Penyusunan Perda Yang Partisipatif: Peran Desa Pakraman Dalam Pembentukan Peraturan Daerah. Zifatama Jawara.

Isrfan Islamy, M., (1997), Prinsip-Prinsip Perumusan Kebijaksanaan Negara, Jakarta, Bumi Aksara

Soerojo Wignjodipuro, (1979), Pengantar dan Asas-Asas Hukum Adat, Edisi ke tiga, Alumni Bandung.

Windia, Wayan P dan Sudantra, Ketut, (2016), Pengantar Hukum Adat Bali, Swasta Nulus bekerjasama dengan Bali Shanti, Pusat Pelayanan Konsultasi Adat dan Budaya Bali LPPM Unud dan Puslit Hukum Adat LPPM Unud

\section{Jurnal}

Dewi, A. A. I. A. A. (2014). Eksistensi Otonomi Desa Pakraman dalam Perspektif Pluralisme Hukum. Jurnal Magister Hukum Udayana (Udayana Master Law Journal), 3(3).

Dewi, A. A. I. A. A. (2015). Dasar Kewenangan Pemerintah Daerah Kabupaten Badung dalam Memberikan Standar Pelayanan Bagi Perempuan dan Anak Korban Kekerasan. Jurnal Magister Hukum Udayana (Udayana Master Law Journal), 4(3).

Dewi, A. A. I. A. A., \& Winarni, L. N. (2019). PENJABARAN PRINSIP DEMOKRASI DALAM PEMBENTUKAN KEBIJAKAN

DAERAH. Supremasi Hukum: Jurnal Penelitian Hukum, 28(1)

Simanjuntak, B. A. (2018). Strategi dan Problem Sosial Politik Pemerintahan Otonomi Daerah Indonesia: Konsep Mensukseskan Otonomi Daerah. Yayasan Pustaka Obor Indonesia. 
Sudantra, I. K. (2018). Implikasi Keputusan Menteri ATR/Kepala BPN Nomor 276/KEP-19.2/X/2017 Terhadap Kedudukan Tanah Milik Desa Pakraman. Jurnal Magister Hukum Udayana (Udayana Master Law Journal), 7(4).

Sirtha, I Nyoman, (2001) , Pengkajian Hukum Adat Bali: Inventarisasi dan Identifikasi Karakteristik Hukum Tanah Adat Bali d I Kabupaten Gianyar, Laporan Penelitian, Kerjasama Pemerintah Daerah Provinsi Bali denggan Fakultas Hukum Universitas Udayana.

Saifullah, S., Ikbal, M., \& Thamrin, H. (2019). IMPLEMENTASI KEBIJAKAN PERATURAN DAERAH NOMOR 18 TAHUN 2016 TENTANG KAWASAN TANPA ROKOK DI RUMAH SAKIT ARIFIN NU'MANG KABUPATEN SIDENRENG RAPPANG. MODERAT: Jurnal Ilmiah Ilmu Pemerintahan, 5(1).

\section{Peraturan Perundang-Undangan}

Undang-Undang Dasar Negara Republik Indonesia Tahun 1945.

Peraturan Pemerintah Nomor 38 Tahun 1963 Tentang Penujukan Badan Hukum.

Keputusan Menteri Agraria dan Tata Ruang/ Kepala Badan Pertanahan Nasional Republik Indonesia Nomor 276/KEP-19.2/X/2017 tentang Penunjukan Desa Pakraman di Provinsi Bali sebagai Subjek Hak Kepemilikan Bersama (Komunal) Atas Tanah.

Peraturan Daerah Provinsi Bali Nomor 4 Tahun 2019 tentang Desa adat Di Bali. 